\section{Epibrassinolide Does Not Enhance Heat Shock Tolerance and Antioxidant Activity in Moth Bean}

\author{
Abha Upadhyaya, Tim D. Davis, and Narendra Sankhla ${ }^{1}$ \\ Texas A\&M University Research and Extension Center, Texas \\ Agricultural Experiment Station, 17360 Coit Road, Dallas, \\ TX 75252-6599
}

Additional index words. brassinosteroids, electrolyte leakage, enzymes, growth regulator, stress, Vigna aconitifolia

\begin{abstract}
Moth bean (Vigna aconitifolia Jacqu. Marecbal cv. Jaadia) seeds were germinated in 0, 0.1, 1, or $2 \mu \mathrm{M}$ EBL. After 72 hours, seedlings were exposed to 22 or $48 \mathrm{C}$ for 90 minutes. At $48 \mathrm{C}$, EBL increased total electrolyte, $\mathrm{K}_{+}$, and sugar leakage from the seedlings relative to the control. Following exposure to $48 \mathrm{C}$, EBGtreated seedlings bad higher malondialdebyde concentrations than controls, indicating that EBL enhanced high-temperature-induced lipid peroxidation. At 48C, EBL increased ascorbic acid oxidase activity but decreased superoxide dismutase activity relative to the control. Taken collectively, these data do not support a hypothesis that brassinosteroids confer beat shock tolerance to moth bean. Chemical name used: 24-epibrassinolide (EBL).
\end{abstract}

The brassinosteroids are a group of recently discovered compounds that are widely distributed among higher plants. They have been reported to influence a variety of growth and developmental phenomena, but their precise physiological and biochemical roles are undefined. Some evidence indicates that the brassinosteroids have a role in cell elongation and perhaps cell division (Mandava, 1988). Brassinosteroids, at micromolar and lower concentrations, have promoted growth in a variety of bioassays, including carrot cell cultures (Bellincampi and Morpugo, 1988), mung bean epicotyls (Gregory and Mandava, 1982), cherry pollen tubes (Hewitt et al., 1985), and wheat coleoptiles (Sasse, 1985).

Brassinosteroids have several potential agricultural applications (Mandava, 1988); among these is the potential for conferring stress tolerance to crop plants. For example, based on preliminary observations, Hamada et al. (1985) and Hamada (1986) suggested that brassinosteroids enhance crop resistance

Received for publication 1 Nov. 1990. We thank Nobuo Ikekawa for supplying the EBL used in this study. Contribution no. 25651 from the Texas Agricultural Experiment Station. The cost of publishing this paper was defrayed in part by the payment of page charges. Under postal regulations, this paper therefore must be hereby marked advertisement solely to indicate this fact.

'Permanent address: Dept. of Botany, Univ. of Jodhpur, Jodhpur, India 342001. to a variety of stresses, including cold, salt, herbicides, and certain diseases. To our knowledge, no research has yet been aimed at evaluating the influence of brassinosteroids on heat shock tolerance. Because cross tolerance (i.e., where tolerance to one type of stress is accompanied by tolerances to other stresses) is a common occurrence in plants, such research is relevant. The present investigation, therefore, was conducted to determine if EBL, a highly active brassinosteroid, would reduce symptoms of heat shock damage in moth bean seedlings. Further, we sought to determine if any changes in heat shock tolerance are correlated with the activities of antioxidant systems considered to be important in plant stress tolerance (Larson, 1988). Moth bean was used as the test material because of its importance as a protein source in arid and semi-arid zones of the tropics where high-temperature tolerance is of considerable interest.

Seeds of moth bean were surface sterilized with $10 \%$ sodium hypochlorite for $10 \mathrm{~min}$, rinsed thoroughly, and placed in the dark at $22 \mathrm{C}$ in petri dishes on filter paper moistened with $0,0.1,1$, or $2 \mu \mathrm{M}$ solutions of EBL. After the cotyledons were excised, uniform seedlings weighing $\approx 70 \mathrm{mg}$ and possessing 3 -cm-long radicles were rinsed in distilled water and used for the subsequent high-temperature exposure. Ten seedlings per treatment were incubated in a test tube containing $10 \mathrm{ml}$ of distilled water at 22 or $48 \mathrm{C}$ (controlled by a constant-temperature water bath to $\pm 0.1 \mathrm{C}$ ) for $90 \mathrm{~min}$. The heat shock temperature and duration were chosen based on previous experience (Upadhyaya et al., 1990). After the exposure to 22 or $48 \mathrm{C}$, total electrolyte leakage from the seedlings was determined by measuring the electrical conductivity of the ambient solution by use of a Beckman RC-16C conductivity bridge (Beckman Instruments, Palo Alto, Calif.). The $\mathrm{K}+$ concentration in the solution was determined using a Perkin-Elmer 5000 atomic absorption spectrophotometer (Perkin-Elmer, Nonvalk, Conn.), and the sugar concentration was determined calorimetrically according to Dubois et al. (1956).

The concentrations of malondialdehyde and proline in the seedlings were determined immediately following the high-temperature treatment. The concentration of malondialdehyde, a product of polyunsaturated fatty acid peroxidation, was determined from centrifuged extracts in 5\% trichloroacetic acid (Dhindsa et al., 1981; Heath and Packer, 1968). Absorbance of the extract was read at $532 \mathrm{~nm}$ and values were corrected for nonspecific turbidity by subtracting the absorbance at $600 \mathrm{~nm}$. The concentration of malondialdehyde was calculated based on its extinction coefficient (Heath and Packer, 1968). Proline concentration was measured using the calorimetric method of Bates et al. (1973).

Ascorbic acid oxidase (E.C. 1.10.3.3) was extracted from the seedlings as described by Esaka et al. (1988). Activity of this enzyme was determined by following the decline in absorbance of the reaction mixture at $265 \mathrm{~nm}$ (Oberbacher and Vines, 1963). The activity of superoxide dismutase (E.C. 1.15.1.10) was determined from seedling extracts prepared according to Upadhyaya et al. (1985) and quantified by measuring the photochemical reduction of nitro blue tetrazolium (Dhindsa et al., 1981). The reaction medium was modified according to Rabinowitch and Sklan (1980). Peroxidase (E.C. 1.11.1.7) and catalase (E.C. 1.11.1.6) were extracted from the seedlings as described by Upadhyaya et al. (1985). Activities of these enzymes were determined by measuring the ability of the extracts to catabolize hydrogen peroxide (Maehly and Chance, 1959).

The experiment was conducted four times. All associated biochemical analyses were performed with two replicate samples per treatment. Each replicate sample was composed of two seedlings. Statistical inferences were made based on a series of $t$ tests between means.

Exposure of the seedlings to $48 \mathrm{C}$ dramatically increased electrolyte leakage compared to $22 \mathrm{C}$, as indicated by the electrical conductivity (Table 1). Furthermore, EBL 
Table 1. Total electrolytes, $\mathrm{K}_{+}$, and sugar released from moth bean seedlings grown in the presence of EBL and then exposed to 22 or $48 \mathrm{C}$ for $90 \mathrm{~min}$.

\begin{tabular}{|c|c|c|c|c|c|c|c|c|}
\hline \multirow{4}{*}{$\begin{array}{c}\text { Solution } \\
\text { characteristic }\end{array}$} & \multicolumn{8}{|c|}{ Temp $\left({ }^{\circ} \mathrm{C}\right)$} \\
\hline & \multicolumn{4}{|c|}{22} & \multicolumn{4}{|c|}{48} \\
\hline & \multicolumn{8}{|c|}{ EBL concn $(\mu M)$} \\
\hline & 0 & 0.1 & 1 & 2 & 0 & 0.1 & 1 & 2 \\
\hline $\begin{array}{l}\text { Electrical conductivity } \\
\left(\mathrm{dS} \cdot \mathrm{g}^{-1} \text { fresh wt }\right) \\
\mathrm{K}^{+} \text {concn }\end{array}$ & $0.72 d^{z}$ & $0.77 \mathrm{c}$ & $0.80 \mathrm{c}$ & $0.84 \mathrm{c}$ & $2.89 \mathrm{~b}$ & $3.24 \mathrm{a}$ & $3.29 \mathrm{a}$ & $3.50 \mathrm{a}$ \\
\hline $\begin{array}{l}\left(\mu g \cdot g^{-1} \text { fresh wt) }\right. \\
\text { Sugar concn }\end{array}$ & $148 \mathrm{~d}$ & $152 \mathrm{~cd}$ & $158 \mathrm{~cd}$ & $164 \mathrm{c}$ & $452 \mathrm{~b}$ & $603 \mathrm{a}$ & $590 \mathrm{a}$ & $710 \mathrm{a}$ \\
\hline$\left(\mu g \cdot g^{-1}\right.$ fresh wt) & $324 \mathrm{e}$ & $376 \mathrm{de}$ & $387 \mathrm{~d}$ & $401 \mathrm{~d}$ & $2180 \mathrm{c}$ & $2640 \mathrm{ab}$ & $2530 \mathrm{~b}$ & $2780 a$ \\
\hline
\end{tabular}

"Mean separation within a row by $t$ tests, $P=0.05$.

Table 2. Malondialdehyde (MDA) and proline concentrations in moth bean seedlings grown in the presence of EBL and then exposed to 22 or $48 \mathrm{C}$ for $90 \mathrm{~min}$.

\begin{tabular}{|c|c|c|c|c|c|c|c|c|}
\hline \multirow[b]{4}{*}{ Compound } & \multicolumn{8}{|c|}{ Temp $\left({ }^{\circ} \mathrm{C}\right)$} \\
\hline & \multicolumn{4}{|c|}{22} & \multicolumn{4}{|c|}{48} \\
\hline & \multicolumn{8}{|c|}{ EBL concn $(\mu \mathrm{M})$} \\
\hline & 0 & 0.1 & 1 & 2 & 0 & 0.1 & 1 & 2 \\
\hline $\begin{array}{l}\text { MDA (nmol } \cdot g^{-1} \\
\text { fresh wt) } \\
\text { Proline }\left(\mu g^{\cdot} \cdot g^{-1}\right.\end{array}$ & $4.5 c^{z}$ & $5.3 \mathrm{~b}$ & $5.0 \mathrm{bc}$ & $5.5 \mathrm{~b}$ & $5.5 \mathrm{~b}$ & $6.5 \mathrm{ab}$ & $6.6 \mathrm{ab}$ & $6.9 \mathrm{a}$ \\
\hline fresh wt) & $61 \mathrm{abc}$ & 66 abc & $68 \mathrm{ab}$ & $72 \mathrm{a}$ & $60 \mathrm{bc}$ & $52 \mathrm{c}$ & $49 \mathrm{c}$ & $47 \mathrm{c}$ \\
\hline
\end{tabular}

${ }^{2}$ Mean separation within a row by $t$ tests, $P=0.05$.

Table 3. Ascorbic acid oxidase, superoxide dismutase, peroxidase, and catalase activities in moth bean seedlings grown in the presence of EBL and then exposed to 22 or $48 \mathrm{C}$ for $90 \mathrm{~min}$.

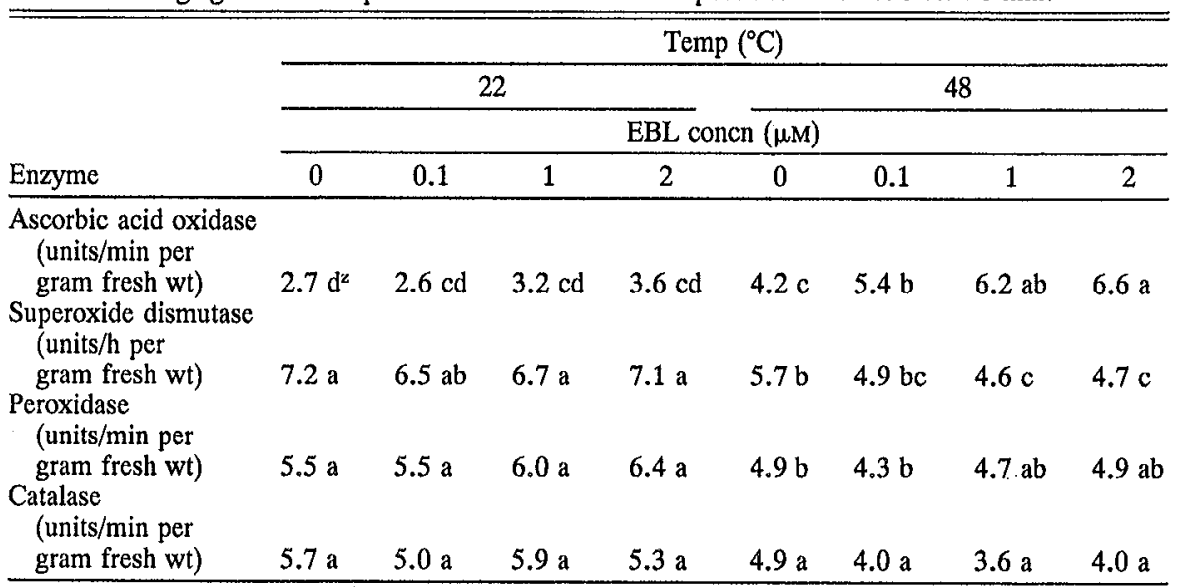

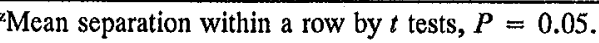

increased electrolyte leakage relative to the untreated control. The largest increase in electrolyte leakage occurred with $2 \mu \mathrm{M} \mathrm{EBL}$ at $48 \mathrm{C}$, where leakage increased by slightly more than $20 \%$ compared to the control. Similar observations were made regarding $\mathrm{K}+$ and sugar efflux (Table 1). High-temperature damage in plants has been associated with reduced membrane integrity and increased electrolyte leakage from cells (Ahrens and Ingram, 1988; Ingram, 1986; Martineau et al., 1979). Hence, these data suggest that EBL did not confer heat shock tolerance and may have even increased high-temperature damage in moth bean seedlings.

Seedlings exposed to $48 \mathrm{C}$ had malondialdehyde concentrations $\approx 20 \%$ higher than those exposed to 22C (Table 2). Malondialdehyde is formed during the peroxidation of fatty acids, which typically accompanies cellular damage (Chevrier et al., 1988).
Hence, these data indicate that high temperature increased lipid peroxidation. A similar response has been observed in soybean seedling roots exposed to high temperature (Upadhyaya et al., 1990). Following exposure to $48 \mathrm{C}$, seedlings treated with $2 \mu \mathrm{M}$ EBL had a malondialdehyde concentration that was $\approx 25 \%$ higher than that of the $48 \mathrm{C}$ control. This result suggests that EBL increased high-temperature-induced lipid peroxidation. These findings support our observations that EBL did not confer heat shock tolerance and may have even increased high-temperature-induced damage to the seedlings.

EBL had no significant effect on proline concentration of the seedlings at 22 or $48 \mathrm{C}$ (Table 2). Some investigators postulated that proline accumulation is a symptom of stressinduced damage (Bhaskaran et al., 1985; Hanson et al., 1977). This postulate is not supported by our current data, where EBL had no clear effect on proline concentration but increased cellular leakage and lipid peroxidation at $48 \mathrm{C}$.

Exposure to $48 \mathrm{C}$ increased ascorbic acid oxidase activity by more than $50 \%$ (Table $3)$. At $22 \mathrm{C}$, EBL had no significant effect on the activity of ascorbic acid oxidase. At 48C, however, EBL enhanced the activity of this enzyme. Treatment of the seedlings with $2 \mu \mathrm{M}$ EBL increased ascorbic acid oxidase activity by nearly $60 \%$ at $48 \mathrm{C}$. Thus, EBL increased the activity of an enzyme that degrades an important antioxidant, ascorbic acid.

EBL had no effect on superoxide dismutase activity at $22 \mathrm{C}$, but decreased the activity of this enzyme at 48C (Table 3). Activity was decreased nearly $20 \%$ by $2 \mu \mathrm{M}$ EBL at $48 \mathrm{C}$ relative to the control at $48 \mathrm{C}$. Superoxide dismutase is an important antioxidant system in plants that scavenges free radicals and has been implicated in mediating cellular response to stress (Larson, 1988). EBL had no significant effects on peroxidase and catalase (Table 3), two other important plant antioxidant systems.

Taken together, our data do not support the hypothesis that brassinosteroids enhance plant tolerance to heat shock. On the contrary, our leakage and malondialdehyde data suggest that EBL increased damage to moth bean seedlings exposed to high temperature. Furthermore, EBL 1) reduced the activity of superoxide dismutase, which has been implicated in protecting plants against stressinduced cellular damage, and 2) enhanced the activity of ascorbic acid oxidase, which degrades an important cellular antioxidant.

\section{Literature Cited}

Ahrens, M.J. and D.L. Ingram. 1988. Heat tolerance of citrus leaves. HortScience 23:747748

Bates, L.S., R.P. Waldren, and I.D. Teare. 1973. A rapid method of proline estimation in water stressed plants. Plant \& Soil 39:205-207.

Bellincampi, D. and G. Morpugo. 1988. Stimulation of growth in Daucus carota L. cell cultures by brassinosteroid. Plant Sci. .54:153-156.

Bhaskaran, S., R.H. Smith, and R.J. Newton 1985. Physiological changes in cultured sorghum cells in response to induced water stress. I. Free proline. Plant Physiol. 79:266-269.

Chevrier, N., F. Sarhan, and Y.S. Chung. 1988 Oxidative damage and repair in Euglena gracilis exposed to ozone. I. SH groups and lipids. Plant Cell Physiol. 29:321-327. 
Dhindsa, R.S., P. Plumb-Dhindsa, and T.A. Thorpe. 1981. Leaf senescence correlated with increased levels of membrane permeability and lipid peroxidation, and decreased levels of superoxide dismutase and catalase. J. Expt. Bot. 126:93-101.

Dubois, M., K.A. Gilles, J.K. Hamilton, P.A. Rebers, and F. Smith. 1956. Colorhnetric method for determination of sugars and related substances. Anal. Chem. 28:350-356.

Esaka, M., J. Imagi, K. Suzuki, and K. Kubota. 1988. Formation of ascorbate oxidase in cultured pumpkin cells. Plant Cell Physiol. 29:231235.

Gregory, L.E. and N.B. Mandava. 1982. The activity and interaction of brassinolide and gibberellic acid in mung bean epicotyls. Physiol. Plant. 54:239-243.

Hamada, K., S. Nishi, T. Uezono, S. Fujiwara, and Y. Nazakawa. 1985. Brassinolide: Some possibilities on agricultural use. Abstr. Intl. Plant Growth Substances Assn., Heidelberg. p. 43.

Hamada, K. 1986. Brassinolide in crop cultivation, p. 190-196. In: P. McGregor (ed.). Plant growth regulators in agriculture. Food \& Fert. Technol. Ctr., Taipei.

Hanson, A.D., C.E. Nelson, and E.H. Everson. 1977. Evaluation of free proline accumulation as an index of drought resistance using two contrasting barley cultivars. Crop Sci. 17:720-726.

Heath, R.L. and L. Packer. 1968. Photoperoxidation in isolated chloroplasts. I. Kinetics and stoichiometry of fatty acid peroxidation. Arch. Biochem. Biophys. 125:189-198.

Hewitt, F.R., T. Hough, P. O'Neill, J.M. Sasse, E.G. Williams, and K.S. Rowan. 1985. Effect of brassinolide and other growth regulators on the germination and growth of pollen tubes of Prunus avium using a multiple hanging-drop assay. Austral. J. Plant Physiol. 12:201-211.

Ingram, D.L. 1986. Root cell membrane heat tolerance of two dwarf hollies. J. Amer. Soc. Hort. Sci. 111:270-272.

Larson, R.A. 1988. The antioxidants of higher plants. Phytochemistry 27:969-978.

Maehly, A.C. and B. Chance. 1959. The assay of catalases and peroxidases, p. 357-425. In: D. Glick (ed.). Methods of biochemical analysis. vol. 1. Interscience Publishing, New York.

Mandava, N.B. 1988. Plant growth-promoting brassinsteroids. Annu. Rev. Plant Physiol. Plant Mol. Biol. 39:23-52.

Martineau, J.R., J.E. Specht, J.H. Williams, and C.Y. Sullivan. 1979. Temperature tolerance in soybeans. I. Evaluation of a technique for assessing cellular membrane thermostability. Crop Sci. 19:75-78.

Oberbacher, M.F. and H.M. Vines. 1963. Spectrophotometric assay of ascorbic acid oxidase. Nature (London) 197:1203-1204.

Rabinowitch, M.D. and D. Sklan. 1980. Superoxide dismutase: A possible protective agent against sunscald in tomatoes (Lycopersicon $e s$ culentum Mill.) Planta 148:162-167.

Sasse, J.M. 1985. The place of brassinolide in the sequential response to plant growth regulators in elongating tissue. Physiol. Plant. 63:303-308.

Upadhyaya, A., T.D. Davis, M.H. Larsen, R.W. Walser, and N. Sankhla. 1990. Uniconazoleinduced thermotolerance in soybean seedling root tissue. Physiol. Plant. 79:78-84.

Upadhyaya, A., D. Sankhla, T.D. Davis, N. Sankhla, and B.N. Smith. 1985. Effect of paclobutrazol on the activities of some enzymes of activated oxygen metabolism and lipid peroxidation in senescing soybean leaves. J. Plant Physiol. 121:453-461. 